\title{
Egy diszkont légitársaság mint márkaközösség a közösségi médiában?
}

\section{A low-cost airline as a brand community in social media?}

\author{
Szerzők: Füredi Anita' - Csordás Tamás
}

\begin{abstract}
A közösségi média könnyen elérhető lehetőséget biztosít a márkák számára felülről vezérelt virtuális közösségek létrehozására. Kellő feltételek mellett a márkaközösségi működés sikeressége számos pozitív vállalati hozadékkal szolgálhat. Kutatásunkban egy speciális iparág (diszkont légitársaságok) egy kiválasztott márkájának, a Wizzairnek a hivatalos Facebook-oldalán található posztok $\left(n_{1}=206\right)$ és hozzászólásaik $\left(n_{2}=536\right)$ netnográfiai elemzését végeztük el. Azt vizsgáltuk, hogy mely bejegyzéstípusok váltják ki a legnagyobb felhasználói reakciót, és milyen a posztokra adott reakciók hangvétele. Eredményeink alapján - az előzetes feltételezésünknek ellentmondva - a márka egy a fogyasztóorientált kommunikációra nagy hangsúlyt fektető és vonzó képet mutat, noha a felhasználói hozzászólások többségében ezt árnyalják a nyereményjátékok, a kontextuson kívüli ügyfélszolgálati jellegű fogyasztói megnyilvánulások és az inkább semleges (semmint kifejezetten pozitív) szentiment.
\end{abstract}

Social media offer a rather easy way to introduce top-down establishment and management for brands of virtual communities. The success of a brand community operation may provide a positive return for the company under optimal conditions. Our research consists of a netnographic analysis of posts $(n 1=206)$ and comments $(n 2=536)$ on the official Facebook page of chosen lowcost carrier Wizzair. We investigate which types of post elicit the higher number of comments from users, and what the tone of user response is to these posts. Contrary to our prior assumptions, our results show a strong emphasis on consumer-oriented communication and, overall, an attractive organization. Our results, however, are slightly influenced by the presence of sweepstakes, outof-context consumer reactions in search of customer service, and an overall neutral (instead of markedly positive) sentiment in user comments.

Kulcsszavak: márkaközösség, diszkont légitársaság, reputációmenedzsment, fogyasztói megítélés.

Keywords: brand community, low-cost airline, reputation management, consumer perception.

\section{Bevezetés}

A Facebook mint virtuális közösségi platform számos közösségnek, köztük márkaközösségeknek, ad helyet. FOURNIER és AVERY (2011) szerint a márkák jelenléte a közösségi médiában korántsem esszenciális, hiszen a platform az emberi kapcsolatok ápolására hivatott, nem pedig arra, hogy a márkák így érjék el a fogyasztókat. Ennek ellenére az online márkaközösségek hozzájárulhatnak a márka és a fogyasztók közti kapcsolat erôsödéséhez, noha ehhez az is szükséges, hogy a vállalat felés megismerje a közösségi média és közö(n|s)sége sajátos múködési mechanizmusait, és ne a hagyományos tömegkommunikációs rutinokat próbálja itt is alkalmazni (BAIRD-PARASNIS 2011, PISKORSKI 2011). A virtuális márkaközösségek létjogosultságát alátámasztja, hogy a fogyasztói döntések számos esetben - különösen az utazási szolgáltatások esetében - az interneten található információkon alapulnak, továbbá az, hogy az online márkaközösségek az adott márka iránti húség megerősítésében is fontos szerepet töltenek be (ld. például SUN et al. 2020).

A tanulmányunk fókuszában álló diszkont légitársaságok szolgáltatásainak érdekessége, hogy

MSc-hallgató, Budapesti Corvinus Egyetem, anita.furedi@stud.uni-corvinus.hu

${ }^{2}$ egyetemi adjunktus, Budapesti Corvinus Egyetem, tamas.csordas@uni-corvinus.hu 
igénybevételük magas fogyasztói érdekeltséggel írható le - például az utazás mint megatrend (MÁLOVICS et al. 2015), a státusfogyasztás jellege (CHAN et al. 2016), avagy bizonytalansága, például a dinamikus árazás miatt (OMARLI et al. 2018) -, miközben olybá túnik, hogy a fogyasztói kérések és panaszok kezelése e vállalatok oldaláról nézve enyhén szólva is bonyolult kérdéskör, amit például vezetóik olykor provokatív médiamegnyilvánulásai is tükröznek: „Nem akarjuk hallani a nyavalygásaitokat. A nem jár visszatérités melyik részét nem értitek?" (Michael O'Leary, CEO, Ryanair) ${ }^{3}$;"Eljön a pont, amikor fizikailag lehetetlenné válik a fogyasztók védelme." (Váradi József, CEO, Wizzair) ${ }^{4}$. Ennek ellenére a tanulmányunk központi vizsgálati elemeként választott Wizzair légitársaság hivatalos Facebook-oldalán az elsô megfigyeléseink alapján korántsem ilyen komor a helyzet. Ezen ellentmondás vizsgálata azért fontos, mert a közösségi média felületein múködő márkaközösségek kihathatnak egy márka egyéb médiafelületeken történő megjelenésére, és ezáltal a reputációjára (VERMEER et al. 2017). Tanulmányunkban azt vizsgáljuk, hogy mely, a Wizzair által közzétett Facebook-bejegyzéstípusok váltják ki a legnagyobb felhasználói reakciót, és milyen a posztokra adott felhasználói hozzászólások hangvétele.

\section{Elméleti összefoglaló}

\subsection{MÁRKAKÖZÖSSÉGEK}

A márkaközösség „,egy olyan földrajzilag kötetlen, specializált közösséget takar, mely az adott márka rajongóinak strukturált kapcsolataira épül" (MUNIZ-O'GUINN 2001: 412). A definícióban a strukturált kapcsolatok a fogyasztó és a márkát képviselő márkatulajdonos kapcsolatára utalnak, melyet többek között az információmegosztás jellemez, és hozzájárulnak a márkaközösség tagjai lojalitásának megőrzéséhez mind a közösség, mind a márka iránt. A márkatulajdonos azonban nem szükségszerú velejárója egy márkaközösségnek. Az alulról építkezô márkaközösségek a márkatulajdonos központi jelenléte nélkül is képesek létezni. A márkaközösségeket három fő pillér megléte határozza meg: (1) rituálék és tradíciók, (2) morális felelősség, (3) közös (megosztott) öntudat (MUNIZ-O'GUINN 2001). A rituálék és tradíciók a tagok közös tulajdonságait jelentik (például szóhasználat), a morális felelősség az integráció és az elkötelezódés fenntartásában játszik fontos szerepet, míg a közös öntudat segít megkülönböztetni a valódi tagokat a kívülállóknak tekintettektól.
McALEXANDER és szerzôtársai (2002) alapján a márkaközösségek jelentősége az adott márkához társítható fogyasztói élményeken alapszik.

A márkaközösségekkel való azonosulás hajtóereje két tényezőbool fakadhat (DEMIRAYBURNAZ 2019). Az úgynevezett vállalati oldali hajtóerốk közé sorolhatók a vállalat által közzétett tartalmak, melyeken keresztül a márkaközösség tagjai passzív élményekhez jutnak (hedonikus elónyök). Ezzel szemben a fogyasztói oldali hajtóerők közé a fogyasztók által észlelt elónyök sorolhatók, melyek a márkaközösségi tagságból származnak, mint például a naprakészség vagy a promóciókkal kapcsolatos információk és gazdasági előnyök megszerzése.

Megkülönböztethetünk továbbá felülról, illetve a tagok által vezérelt márkaközösségeket (PORTER 2004). A felülról vezérelt márkaközösségeket az adott szervezet alapítja és irányítja, míg az alulról, vagyis a tagok által vezérelt márkaközösségeket a szervezettól többé-kevésbé független módon a tagok múk ödtetik. Míg az alulról vezérelt közösségek alapja a tagok közti interakció, a felülről vezéreltek esetén sokkal jellemzóbb a tagok és a szervezet között is kialakuló összeköttetés. Ilyenkor a tagoknak és az adott szervezetnek is lehetôsége nyílik tartalmat szolgáltatni, hogy ezzel erősítse a közösségen belüli kapcsolatokat. A szervezet a tagok interaktivitásra buzdítása és bevonása érdekében foglalkozik közösségteremtéssel (PORTER 2004). A felülről irányított virtuális márkaközösségek segítségével a vállalat és a fogyasztók közötti kapcsolat szorosabbra fúzhetó és javítható (ARNONE et al. 2009). Ezért a vállalatok marketingbefektetésként tekinthetnek ezekre a közösségekre, ahol a cél a már meglévó és a potenciális új fogyasztókkal való hosszú távú kapcsolat kiépítése. Fontos azonban megemlíteni, hogy az ilyen közösségek menedzselése sokszor komoly vállalati erőforrások bevonását igényli, ami sok esetben rejtett költségként jelentkezik (például emberierőforrás-többlet) (LIAO et al. 2017).

A kapcsolat javításának alapját a vállalat által kínált termékekkel és szolgáltatásokkal kapcsolatos pozitív fogyasztói tapasztalatok adják. Azonban a negatív tapasztalatokkal rendelkező fogyasztók vállalathoz való viszonyának javítása közösségimédia-tartalmak segítségével nehézségekbe ütközik, hiszen ezen platformok elsősorban kommunikációs funkciót képviselnek, szemben a sérelmek üzletvitelszerú kiküszöbölésével (GAMBOA-GONÇALVES 2014). A kapcsolat javításának eléréséhez a vállalatnak olyan értékajánlatot kell nyújtania a fogyasztók számára az online

\footnotetext{
${ }^{3}$ https://www.bbc.com/news/business-46364169

${ }^{4}$ https://hvg.hu/gazdasag/20190708_Wizz_Air_Varadi_Jozsef_repules_repulo_utazas_fogyasztovedelem
} 
márkaközösségi múködés során, ami a fogyasztókban azt az érzetet kelti, hogy előnyhöz jutnak a márkaközösséghez való csatlakozás által. Ez az előny származhat a különleges bánásmód érzéséből, a közösségbe tartozás érzetéből, vagy akár a tagságból származó önbizalomnövelés lehetőségéből is. A vállalat fogyasztói kérdésekre adott gyors és megfelelő stílusú válaszai, a gyakori vállalatfogyasztó interakciók, a dinamikus vállalati jelenlét hozzájárulhat a fogyasztók által észlelt megszerezhető előnyök fokozásához (GAMBOAGONÇALVES 2014). A bizalom és az elköteleződés szempontjából mind a hedonikus, mind a gazdasági előnyök segítik a fogyasztók és a vállalat közti kapcsolat minőségének javítását. Azonban a fogyasztók által észlelt hedonikus előnyök nagyobb mértékben járulnak hozzá ehhez a javuláshoz, mint a gazdaságiak (AKROUT-NAGY 2018), noha a gyakorlatban rövid távon a gazdasági előnyök jelenléte a fogyasztók oldaláról akár explicit elvárásként is jelentkezhet (BAIRD-PARASNIS 2011).

\subsection{A REPUTÁCIÓMENEDZSMENT KIHÍVÁSAI A DIGITÁLIS TÉRBEN}

Egy vállalat által létrehozott virtuális közösség lehetôséget ad a vállalati reputáció növelésére. Ennek jelentőségét indokolja például az átláthatóság iránti igény, az érintettek növekvő igényei és a vállalati akciókkal kapcsolatos növekvő fogyasztói tudatosság és érdeklődés. Az online térben generált pozitív szájreklám (e-WOM) szintén ide sorolható (SHAMMA 2012). A reputációmenedzsment egy személy vagy szervezet hírnevének irányítását és alakítását jelenti. E folyamat során ez utóbbiak a tömegkommunikációs eszközök (köztük ma már leggyakrabban a közösségi média felületeinek) használatán keresztül próbálnak meg hatást gyakorolni a közösség észlelésére, egyben olyan információkat és értékeket közvetíteni, melyeket az adott személy vagy szervezet láttatni szeretne magáról. A reputációmenedzsmentet gyakran kíséri a negatív információk tudatos háttérbe szorítása és a pozitív hírértékú elemek hangsúlyozása (TASENȚE 2020). Ezt kiegészítendő, JONES és szerzőtársai (2009) a pozicionálást, a monitoring folyamatát és az érintettekkel történó átlátható és etikus párbeszédet a reputációmenedzsment részeként azonosították. Az online reputációmenedzsment a virtuális platformokon történó hírnév-befolyásolás eszköze. Ehhez az információs és kommunikációs technológiák széles körú lehetőségeket nyújtanak, elsősorban az információgyújités és a monitoring területén. A nehezen kontrollálható közösségimédia-felületeken komoly feladat tudatosan menedzselni a vállalati hírnevet
(DIJKMANS et al. 2015). Ennek egyik oka az, hogy a felhasználók szabadon nyilváníthatnak ki a vállalat érdekeivel szembemenő véleményeket. Egyegy nagy visszhangot kiváltó negatív komment nagy károkat okozhat a vállalat hírnevében vagy a márkanévben (MARKOS-KUJBUS-GERENCSÉR 2016). Az üzleti szolgáltatások sajátos tulajdonságaik miatt (ld. „HIPI-elv”) különösen ki vannak téve e fenyegetésnek. ECCLES és szerzőtársai (2007) három okot azonosítottak, amelyek felmerülése esetén a közösségi média reputációs kockázatot jelent: (1) fogyasztói elvárásokban bekövetkezett változás; (2) megnövekedett rés a vállalati múködés valós értékének és hírnevének mértéke között; (3) környezeti változásokhoz való sikertelen alkalmazkodásból következő rossz belső koordináció és döntéshozatal.

A vállalatok korlátozottan képesek az online felületeken megjelenő felhasználói tartalmakat irányítani (MARKOS-KUJBUS 2016). A fogyasztók közti (C2C) kommunikáció során az egyes fogyasztók tudása és információja a vállalattal, a márkával, a termékkel vagy a szolgáltatással kapcsolatban eltérô mélységú és pontosságú, ezáltal az egyes fogyasztói kommentek hitelességüket és megalapozottságukat tekintve egymástól eltéróek lehetnek (ZHU et al. 2016). A többi fogyasztó által megosztott tartalmak hitelességének megítélésében a fogyasztók gyakran nehézségekbe ütköznek, a megfelelő forráskritika alkalmazása háttérbe szorulhat más fogyasztók véleményének feldolgozása közben (CHEUNG et al. 2009). Ezért a közösségimédia-felületeken jelen lévő márkaközösségek reputációjának tudatos menedzselése kiemeleten fontos az üzleti siker elérése és megtartása érdekében (AULA 2010).

\section{Kutatási módszertan}

Kutatásunkban azt vizsgáltuk, hogy mely, a Wizzair által közzétett, Facebook-bejegyzéstípusok váltják ki a legnagyobb felhasználói reakciót, és milyen a posztokra adott felhasználói hozzászólások hangvétele. Tanulmányunk egy netnográfiai módszertanon alapuló kvalitatív tartalomelemzés. A netnográfia filozófia alkalmas az online közösségek felépítésének és múködési mechanizmusainak feltérképezésére (KOZINETS 2015), melynek az alapjául szolgáló információk az internetfelhasználók számára elérhető online platformokról származnak. A megfigyelő netnográfia során a kutató kívülállóként, kvázi szemlélődőként van jelen a közösség életében, de ô maga nem lesz a közösség tagja. Erre egy nyílt, felülról irányított márkaközösség kifejezetten alkalmas. A netnográfia magába foglalja az online leírások, tartalmak meg- 
figyelését, ezek kódolását és a kiválasztott tartalmak elemzését. A tartalomkiválasztási folyamat addig tart, amíg a megértést szolgálja és új szempontokat, nézeteket tud generálni (KOZINETS 2015). A tartalomelemzés során végbemenő kategorizáláson keresztül a kutatók sémákat és logikai alakzatokat, mintákat keresnek. A virtuális közösségekben történô kommunikáció elemzése során pedig nemcsak a vizsgált szövegre vonatkozóan lehet következtetéseket levonni, hanem a szöveg kontextusára, környezetére vonatkozóan is (KRIPPENDORFF 2004). Egy márka hivatalos Facebook-márkaoldalának tartalomelemzése segít annak a feltárásában, hogy a vállalat a közösségi média kommunikációja során hogyan reprezentálja magát. A legnagyobb felhasználói aktivitást kiváltó posztok tartalmi és vizuális elemei között található kombinációk azonosítása segít feltárni a posztok és az aktivizáló hatásuk közti összefüggéseket. A hozzászólások elemzése pedig a felhasználói vélemények és a márkához való fogyasztói viszonyulás megértését segítik.

Kutatásunkban a Covid19-világjárvány torzító hatását kiszúrendő a 2019-es évet vettük alapul. Minden évszakból egy véletlenszerúen kiválasztott hónap teljes, a mintavételkor elérhetô poszt állománya került elemzésre (jan., márc., aug., szept.). Az évszakok reprezentációjára azért volt szükség, mert a légitársaságok múködése során a szezonalitás kulcsfontosságú tényező. A négy elemzett hónap összesen 206 bejegyzése került lementésre.

A kódolás során kiindulásként a posztokat öt tartalmi dimenzió mentén kategorizáltuk (1. típus, 2. üzenet, 3. képi tartalom, 4. irányultság, 5. azonosítható cél). (1) Az elemzés során hét különböző poszttípus rajzolódott ki (edukatív, nyereményjáték, sales, employer branding, CSR, love-post, karrierlehetőség). (2) Posztüzenet alatt a poszt központi motívumát definiáltuk. (3) A bejegyzésekkel közzétett képek elemzése szintén a kutatás részét képezte. (4) A kognitív és az emocionális irányultság vizsgálata során megkülönböztettük az elsősorban érzelmi, az értelmi és a vegyes elemeket tartalmazó posztokat. (5) Utolsó dimenzióként azt vizsgáltuk, hogy inkább a vállalati megítélés befolyásolása (branding) vagy a monetáris ösztönzés (performance) a poszt azonosítható fő célja. Ezen öt dimenzió együttese mentén elemeztük, hogy mely posztjellemzók fordultak elő leggyakrabban a posztok során, illetve hogy mely posztjellemzó kombinációkat tartalmazó posztok váltották ki a legmagasabb összesített felhasználói aktivitásszámot (megosztások, kommentek, reakciógombos aktivitások összessége). A vizsgált 206 poszt átlagosan 687 reakciót generált. A legkevesebb ki- váltott reakció 5, a legmagasabb pedig 7258 volt. Figyelembe véve a kutatási kérdésünket, a 20 legmagasabb aktivitásszámot elérő poszt kiegészítő, részletes szöveges és képi tartalomelemzése következett, amivel a kiugróan magas aktivitás előfordulásának okára kerestük a választ.

Az utolsó elemzési fázis a felhasználói kommentek kiértékeléséből állt. Megvizsgáltuk, hogy poszttípusonként melyek a hozzászólások leggyakoribb tartalmi jellegzetességei, illetve, hogy milyen eredményt ad a kommentek hangvétel alapján készült kvázi-szentimentelemzése. A kommentelemzés során mindegyik poszttípusból két, egyszerú véletlen mintavétellel kiválasztott bejegyzés komment állományának online szoftverrel történő lementésével kapott adatbázisa került kiértékelésre, mely során összesen 536 hozzászólást gyújtöttünk össze és elemeztünk.

\section{Eredmények}

\subsection{A LEGMAGASABB FELHASZNÁLÓI AKTIVITÁST KIVÁLTÓ POSZTOK TARTALOMELEMZÉSE}

A márkaközösség tartalomelemzése során először megvizsgáltuk, hogy az egyes posztjellemzők milyen kapcsolatban állnak a generált aktivitással, és hogy ezen dimenziók mentén milyen mintázatok fedezhetőek fel. Azonosítottuk a legmagasabb (1000 feletti) aktivitásszámmal rendelkezó posztok $(41 \mathrm{db})$ jellemzőit. A kapott eredményeket összehasonlítottuk az összes poszt alapján talált leggyakoribb posztjellemzókkel (1. táblázat). A mintában jelentôs átfedés volt a legmagasabb aktivitásszámú posztok és az összes poszt posztjellemzői között mind az öt vizsgált dimenzió esetében.

Segíti az új tagok csatlakozását a közösséghez, ha a márkaközösségi oldal beszámol az újdonságokról, és informatív tartalmakat is megoszt. Ez a mintában valóban megjelent, a leggyakoribb poszttípus az edukatív, információmegosztó tartalom volt. Figyelemre méltó az is, hogy a mintában a legnagyobb összaktivitású bejegyzések elsősorban nem nyereményjátékok és reakciógombos szavazások segítségével generálódtak. A pénzügyi ösztönzők helyett az imázsfenntartó és építő posztok arattak sikert a vizsgált márkaközösségben.

A kiváltott reakciók típusai szerint is megvizsgáltuk a posztokat, vagyis azt, hogy mely posztjellemzők generálták a legtöbb megosztást, hozzászólást, illetve reakciógomb-aktivitást (2. táblázat).

A legtöbb megosztást produkáló bejegyzések az edukatív és a love-post poszttípusba sorolhatóak, nem volt közöttük nyereményjáték jellegú 
Magas aktivitást kiváltó posztok jellemzői és az összes poszt leggyakoribb jellemzői

\begin{tabular}{|c|c|c|c|}
\hline & $\begin{array}{l}\text { Legmagasabb aktivitást kiváltó } \\
\text { posztok }(n=41) \text { jellemzői }\end{array}$ & $\begin{array}{l}\text { Leggyakoribb posztjellemzők az } \\
\text { összes posztot vizsgálva }(n=206)\end{array}$ & $\begin{array}{c}\text { Leggyakoribb posztjellemzők } \\
\text { az összes poszt } \\
\text { ÉS } \\
\text { a legmagasabb aktivitást kiváltó } \\
\text { posztok esetén }\end{array}$ \\
\hline Poszttipus & $\begin{array}{l}\text { edukatí, employer branding, love- } \\
\text { post }\end{array}$ & edukatív & edukatív \\
\hline Posztüzenet & boldogság, ünneplés & $\begin{array}{l}\text { munkaleirás, felfedezés, kikapcsolódás, } \\
\text { ünneplés }\end{array}$ & ünneplés \\
\hline Képi tartalom & személyzet, repülögépek & személyzet, repülőgépek, desztináció & személyzet, repülőgépek \\
\hline Irányultság & kognitív, emocionális & kognitív & kognitív \\
\hline Cél & branding & branding & branding \\
\hline
\end{tabular}

Forrás: saját minta

Legmagasabb aktivitást elért posztok a különbözó aktivitásformák tekintetében

\begin{tabular}{|l|c|c|c|}
\hline & Magas (>50) megosztásszám (n=14) & $\begin{array}{c}\text { Magas (>1000) reakciógomb- } \\
\text { aktivitás }(n=32)\end{array}$ & $\begin{array}{c}\text { Magas }(>200) \text { hozzászólásszám } \\
(n=17)\end{array}$ \\
\hline Poszttípus & edukatív; love-post & $\begin{array}{c}\text { edukatív; love-post; employer } \\
\text { branding }\end{array}$ & $\begin{array}{c}\text { edukatív; nyereményjáték } \\
\text { Posztüzenet }\end{array}$ \\
\hline $\begin{array}{c}\text { Képi tartalom } \\
\text { boldogság }\end{array}$ & $\begin{array}{c}\text { repülógép/repülés, desztinációg } \\
\text { (térkép), személyzet/Wizzair, } \\
\text { repülőtér }\end{array}$ & $\begin{array}{c}\text { személyzet/Wizzair; repülógép/ } \\
\text { repülés }\end{array}$ & $\begin{array}{c}\text { repülógép/repülés, desztináció } \\
\text { (térkép) }\end{array}$ \\
\hline Irányultság & kognitív, emocionális & emocionális & kognitív, emocionális, vegyes \\
\hline Cél & branding & branding & branding, performance \\
\hline
\end{tabular}

Forrás: saját minta

bejegyzés. Az üzenetet tekintve a "boldogság" asszociációra reagáló posztok voltak egyértelmú többségben. Ezzel szemben a képi tartalom és a megosztásszám között nem volt látható egyértelmú összefüggés, többféle képtípus is sikert aratott. Ez az állítás szintén igaz a poszt irányultsága kapcsán. Kifejezetten emocionális vagy kifejezetten kognitív elemeket tartalmazó posztok is generáltak magas megosztásszámot. A poszt által megcélzott hatást tekintve a vállalati megítélés befolyásolására irányuló posztok rendelkeztek magas megosztásszámbeli aktivizációs rátával.

A magas reakciógomb-aktivitást kiváltó posztok esetében is a „boldogság” asszociációra reagáló, fő́ként edukatív, love-post és employer branding típusú posztok voltak többségben. A megosztásszám dimenzióhoz hasonlóan, ebben a dimenzióban is a vállalati megítélést befolyásoló posztok arattak sikert.

A legtöbb hozzászólást kiváltó posztok között már megjelentek a nyereményjátékot tartalmazó posztok is, ezáltal a mintában a vállalati megítélés növelése mellett a monetárisan ösztönzó posztok is sikert arattak az aktivizálásban. Ez a részeredmény alátámasztja a szakirodalom abbéli következtetéseit, hogy a márkákkal történő fogyasztói interakcióban nagy szerepe van az egyéni, haszonalapú megközelítésnek is, noha ez nem jár mélyebb fogyasztói elköteleződéssel (vö. megosztás) (ld. például BAIRD-PARASNIS 2011).

A mintában tehát hasonló jellemzők generálják a legmagasabb felhasználói aktivitást a bejegyzésekre, legyen szó megosztásról, reakciógomb-használatról vagy hozzászólásokról. A magas felhasználói aktivitást kiváltó posztok jellemzően edukatív és love-post típusúak, melyek központi üzenetében a boldogság áll, a wizzaires személyzetet, dolgozókat vagy repülőgépeket, repülést ábrázoló képeket tartalmaznak és a vállalat megítélésének befolyásolása a céljuk. Az értelmi és az érzelmi válaszreakciót kiváltó posztok egyaránt magas aktivitást tudnak generálni, viszont a ve- 
gyes, vagyis a mind érzelmi, mind értelmi hatást megcélzó bejegyzések kevésbé sikeresek az aktivitásgenerálásban.

A képi tartalom alapján a legsikeresebb húsz posztot elemeztük, amely során két csoport rajzolódott ki. Az egyikben a légiutas-kísérók képeit tartalmazó posztok emelkednek ki (1. ábra/a,b). Ók a mintában attraktív, mosolygós személyek, egyenkosztümük árulkodik arról, hogy a Wizzair munkavállalói. Egyéni és csoportos ábrázolásuk egyaránt előfordul, jellemzően előre beállított helyzetekben, illetve néhol gyermek utassal közösen ábrázolva, láthatóan rájátszva az úgynevezett "cukiságfaktorra". Jellemzőek a közösségi média divatos kreatív megoldásai, például a kézzel megformált szívecske, a kacsintás, a szelfinézópont. Egyes szövegelemek (például saját hashtag [\#IamWIZZcrew], illetve megjelölt, taggelt márkanagykövet) összekötô elemként funkcionálnak egyéb tartalmak irányába, ezáltal a posztok közötti kapcsolatot és a közösségformáló attribútumokat hangsúlyozzák ki, csakúgy, mint annak említése, hogy egy-egy kép a kolléga jóvoltából került publikálásra. Közös e bejegyzésekben a felhasználók megszólítása, a kreatív megfogalmazásmód, a vonzó képi tartalom (attraktivitás, vidám hangulat, imázsépítő funkció) és a közös kapcsolóelemek megléte. Egy professzionális, fogyasztóorientált, barátságos és összetartó vállalat képét keltik. A másik sikeres képi tartalom csoport további két alcsoportra bontható: az egyik alcsoport a vállalat saját repülőgépeit, a másik pedig térképeket ábrázol az új desztinációkról (1. ábra/c, d). A wizzaires repülógépeket jellemzően közelról ábrázolják, könnyen felismerhetô a márka színkódja. A képek nappal készültek, ezzel is vidámságot sugároznak. A desztinációkat térképen bemutató posztok szintén az ikonikus színkombinációt tartalmazzák, jellemző feliratként az „Új útvonalak” szókapcsolat jelenik meg. A kísérőszövegek emoji használata ebben az alcsoportban visszafogottabb, hiszen az első alcsoport gyakori érzelemcélzatú üzeneteivel szemben itt az értelemre hatás jelenik meg.

\subsection{A WIZZAIR ÁLTAL KÖZZÉTETT POSZTOKHOZ TARTOZÓ FELHASZNÁLÓI HOZZÁSZÓLÁSOK TARTALOMELEMZÉSE}

Az egy posztra jutó hozzászólások számát tekintve a nyereményjáték típusú posztok generálták a legmagasabb kommentszámot. Ez annyiban nem meglepó, hogy gyakran a hozzászólók közül választják ki a nyerteseket, emiatt sokan a nyeremény elnyerése érdekében írnak.

A felhasználók által írt hozzászólások két nagy csoportra tagolódnak (3. táblázat). Az egyik rész a poszt tartalmára reagál, illetve a vállalatról alkotott véleményt tartalmaz, míg a másik rész ügyfélszolgálati jellegú, operatív kérdéseket tesz fel, és személyes utazással vagy foglalással kapcsolatos problémákat fogalmaz meg. Noha utóbbi gyakran kontextuson kívül, a felhasználók általi egyfajta akaratlan, deviáns viselkedésként jelenik meg. Azokat tekintettük kapcsolódó kommentnek, amelyek reflektáltak a közzétett bejegyzés vizuális vagy szöveges tartalmára, vagy azok egyes elemeire (4. táblázat). A kapcsolódó hozzászólások négy tartalmi alkategóriában jelentek meg (elismeró/ kritizáló; humoros/ironikus; tartalmat kiegészító/ kérdést megválaszoló; véleményüket elsósorban emojik segítségével kifejezők), míg a nem kapcsolódóak elsôsorban a márka szolgáltatásai kapcsán írtak és osztották meg saját problémáikat.

Az edukatív típusú posztoknál a kommentek között főleg a poszt által közvetített informatív tartalomra történó reflektálás volt jellemzô. Ezen kommentek elsósorban a poszt tartalmát minósítették, értékelték vagy egészítették ki. Emellett

\section{Példák legnépszerúbb képi tartalmakra és kategóriáikra a mintában}
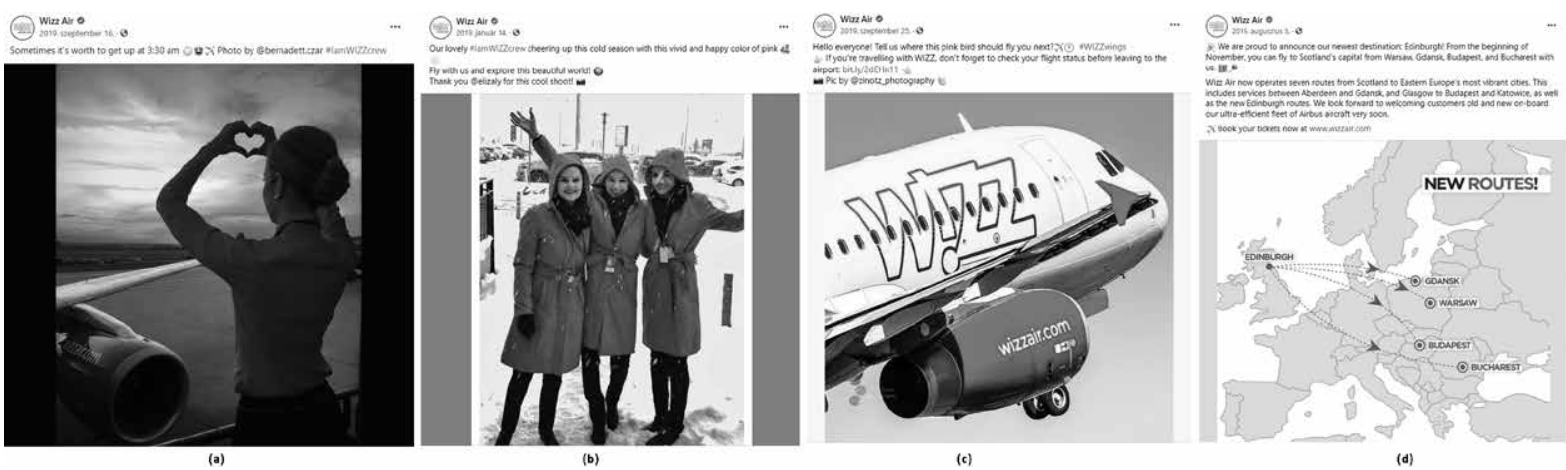

Forrás: https://www.facebook.com/wizzair/ 
A bejegyzésekhez írt hozzászólások poszthoz való viszonya poszttípusonként

\begin{tabular}{|l|c|c|c|c|c|c|c|}
\hline \multicolumn{1}{|c|}{ Poszttípus } & Edukatív & Nyeremény-játék & Sales & $\begin{array}{c}\text { Employer } \\
\text { branding }\end{array}$ & Love-post & Karrier & Össz. \\
\hline Elemzett hozzászólás $(\mathrm{db})$ & 95 & 61 & 68 & 124 & 88 & 100 & 536 \\
\hline $\begin{array}{l}\text { Poszt tartalmához } \\
\text { közvetlenül kapcsolódó }\end{array}$ & 60 & 37 & 43 & 109 & 61 & 56 & 366 \\
\hline $\begin{array}{l}\text { Poszt tartalmához nem } \\
\text { kapcsolódó }\end{array}$ & 35 & 24 & 25 & 15 & 27 & 44 & $\begin{array}{c}170 \\
(68 \%)\end{array}$ \\
\hline
\end{tabular}

Forrás: saját minta

Jellemzô hozzászólástípusok a mintában

\begin{tabular}{|c|c|c|}
\hline & Pozitív vagy semleges hangvételü & Negatív hangvételü \\
\hline & \multicolumn{2}{|c|}{ Poszt tartalmához közvetlenül kapcsolódó } \\
\hline elismerö/kritizáló & „Imádnivaló lányok! Nagyszerú személyzet!" & $\begin{array}{c}\text { "Doncaster - Kosice kérlek! Miért nem hallgattok } \\
\text { az utasaitokra ......" }\end{array}$ \\
\hline humoros/ironikus & $\begin{array}{c}\text { "Emberek, akik nonszenze útvonalakat javasolnak csak mert ott } \\
\text { élnek vagy ott van rokonunk, jönnek 3....2...1..." }\end{array}$ & $\begin{array}{c}\text { „Imáááádok bébikkel együtt repülni!!!- Mondta } \\
\text { soha senki" }\end{array}$ \\
\hline \multirow{2}{*}{$\begin{array}{l}\text { tartalmat kiegészitö/ } \\
\text { kérdést megválaszoló }\end{array}$} & „Hello! Mikor lesz ugyanez a promóció novemberben?" & „Bezzeg Malmö visszavonva” \\
\hline & \multicolumn{2}{|c|}{ Poszt tartalmához nem kapcsolódó } \\
\hline $\begin{array}{l}\text { szolgáltatás iránt } \\
\text { érdeklödő }\end{array}$ & $\begin{array}{c}\text { "Sziasztok, csak egy gyors kérdés: Törlitek a Gothenburg-Wroct } \\
\text { aw útvonalat?" }\end{array}$ & $\begin{array}{c}\text { „Köszi a Wizzair kártya kinyírásat, ezt kicsit } \\
\text { sztem benéztétek" }\end{array}$ \\
\hline saját problémák & $\begin{array}{c}\text { „Hello Wizzair! Pánikszerúen próbálom visszaállitani a } \\
\text { jelszavamat a honlapotokon [...] Kérlek meg tudnátok oldani ezt } \\
\text { a problémát?” }\end{array}$ & $\begin{array}{c}\text { "Hello. Elveszett bốröndömról } 2 \text { hónapja semmi } \\
\text { hír. } 3 \text { panasz válasz nélkül. Átverve érzem } \\
\text { magam." }\end{array}$ \\
\hline
\end{tabular}

Forrás: saját minta

a felhasználók számos, a Wizzair további terveit és fejlesztéseit érintő kérdést is feltettek. A nyereményjáték típusú posztokhoz érkezett hozzászólások többsége valóban a feltett kérdésre adott válasz volt. A sales típusú posztok esetében a kommentek fóleg a poszt tartalmára reflektáltak, valamint egyéb operatív utazási vagy foglalási szabályokkal és múködéssel kapcsolatos kérdésrôl szóltak. Az employer branding típusú posztok többnyire attraktív légiutas-kísérók fotóit tartalmazták. A vizsgált kommentek főként a képen látható hölgyek szépségérôl, kedvességéról és professzionalizmusáról szólnak, de erotikus utalások is felfedezhetőek a hozzászólások között. A love-post típusú posztok esetében a képi tartalmak minősítése volt a leggyakoribb hozzászólástípus. Ezen posztok képtartalma közé sorolható például a gyermek utasok és légiutas-kísérők közös fotója, illetve a légiutas-kísérők egyéni vagy csoportos fényképe. A vizsgált karrierlehetőségek típusú posztok esetében az érkezett 100 kommentból mindössze 56 reagált a meghirdetett pozícióra, a többi kommentelő elsősorban a saját utazással vagy foglalással kapcsolatos kérdéseit és problémáit említette meg.

Mindegyik típusú posztnál visszatérő hozzászólás-tartalom volt más Facebook-felhasználó nevének említése, vagy saját operatív problémák, utazási és foglalási témákkal kapcsolatos kérdések feltevése. Ezen kérdésekre és problémákra a Wizzair márkaközösség neve alatt kommentekben reflektáltak a wizzaires dolgozók, ezáltal a Wizzair márkaközösség Facebook-oldala akaratlanul is egyfajta ügyfélszolgálati jelleget és funkciót töltött be (ld. például LANCELOT-MILTGEN et al. 2019). Ügyfélszolgálati jellegú hozzászólói megnyilvánulás minden poszttípus esetén fellelhető volt, melyekre a márka részéról udvarias és segítőkész válaszok érkeztek. Felhasználó-felhasználó és vállalat-felhasználó között az egymás kommentjeire való reflektálás gyakran közösségi múködést segítő elemként jelent meg. Ennek során a közös élmények és tapasztalatok megosztása, az egymás problémáira való reflektálás, illetve a közös humor is képviseltette magát. Ezen attribútumok a márkaközösségként való múködést támasztják alá. 
A kommenteket végül egy kvázi-szentimentelemzésnek is alávetettük, mely során manuálisan kódoltuk a negatív (,-1" kódolt érték; $n=27)$, a pozitív (,1"; $\left.1^{\prime \prime}=103\right)$ és a semleges $\left(,{ }^{\prime \prime} 0^{\prime \prime} n=406\right)$ hangvételú kommenteket. A szentimentelemzés végeredménye, azaz a kódolt értékek súlyozott átlaga 0,142 lett. A kommentek hangvétele tehát enyhén pozitív volt a mintában, ami bizonyos fokig megerősíti a márkaközösségként való múködést. Ezt természetesen árnyalja, hogy a közösség felülről vezérelt, azaz a márka megbízásából dolgozó adminisztrátoroknak bármikor lehetôsége van a moderálásra, a nem kívánatos tartalmak törlésére. Mindemellett a semlegeshez erősen közelítő érték azt is jelzi, hogy a márka iránti elköteleződés mérsékelt, illetve, hogy sok résztvevő nem kifejezetten a márka iránti elköteleződésből, mint inkább például könynyebbségből, egyfajta alternatív ügyfélszolgálti funkcióért és/vagy egyéni haszonért van jelen.

\section{5. Összegzés}

Feltáró tanulmányunkban, mely a téma egy tágabb vizsgálatának elsô eredményeit foglalja össze, a Wizzair Facebook-márkaközösségének poszt- és kommenttartalmait vizsgáltuk meg. A kutatás érdekessége, különösen a tekintetben, hogy egyre több jel utal a tisztán diszkont modell (vö. SZUTORISZ et al. 2008) korlátozott fenntarthatóságára (ld. például KÖKÉNY et al. 2021), hogy egy diszkont légitársaság, azaz egy a szolgáltatásminőséggel szemben elsősorban áralapú pozicionálást folytató szolgáltató teljesítményét vizsgálja egy kifejezetten élmény- és fogyasztóközpontú közösségi felületen.

A márka hivatalos Facebook-oldaláról vett mintában számos, márkaközösségre jellemzô tulajdonság volt azonosítható, de a monetárisan ösztönző posztok (nyereményjátékok) is megjelentek. A legnagyobb fogyasztói reakciót a márkaépítést szolgáló informatív, edukatív bejegyzések váltották ki, melyekben megjelentek a márka ikonikus elemei (egyenkosztüm, színkód) és sikerei (új útvonal, repülőgéptípus). Érdekesség, hogy annak ellenére, hogy a diszkont légitársaságok modellje elsősorban a költséghatékony múködésre épül, a monetáris ösztönzést elősegítő posztok összességében alacsonyabb reakciószámot váltottak ki, mint a vállalati megítélést befolyásolni próbálóak. A hozzászólások között megjelentek továbbá a saját problémákat taglaló vagy információkérő tartalmak, ugyanakkor általában kontextuson kívül. Noha az ügyfélszolgálati jelleg is segítheti az oldal iránti érdeklődés fenntartását, ennek keretei kevéssé tûnnek meghatározottnak, és az elsősorban imázsépítô tartalmakkal keveredve kérdéses, hogy mennyire szolgálják ilyen formában a hosszú távú közösségi elköteleződést. További érdekes kutatási kérdés lehet, hogy azt itt megjelenó vállalati kép mennyire jelent valós piaci pozíciót, illetve hogyan hasznosítható gazdaságilag ez a márkaközösség. A kutatás limitációi közé tartozik, hogy csak egy szolgáltatót vizsgált, egy kommunikációs csatornán. További kutatási irányként és az érvényesség növelése érdekében javasolható további, többoldalú elemzés lefolytatása, amelyben a különböző forrásból (pl. további szerzettmédia-felületek bevonásából) származó információk kerülhetnek összevetésre. Egy további kutatási irány lehet a márka követői, közössége csatlakozási motivációinak és márkához való viszonyának feltárása annak azonosítására, hogy a jelen kutatásban megjelenó fogyasztási mintázatok mennyire feleltethetőek meg a márka átlagfogyasztói magatartásának.

\section{Felhasznált irodalom}

AKROUT, H. - NAGY, G. (2018): Trust and commitment within a virtual brand community: The mediating role of brand relationship quality. Information $\mathcal{E}$ Management. 55(8). pp. 939-955. https://doi.org/10.1016/j.im.2018.04.009

ARNONE, L. - GEERTS, A. - SCOUBEAU, C. (2009): Implementing company-managed virtual communities as a relationship marketing tool: a decision systems analysis. Journal of Customer Behaviour. 8(1). pp. 5-27. https://doi.org/10.1362/147539209X414362

AULA, P. (2010): Social media, reputation risk and ambient publicity management. Strategy $\mathcal{E}$ Leadership. 38(6). pp. 43-49.

https://doi.org/10.1108/10878571011088069

CHAN, W. Y. - TO, C. K. M. - CHU, W. C. (2016). Desire for experiential travel, avoidance of rituality and social esteem: An empirical study of consumer response to tourism innovation. Journal of Innovation \& Knowledge. 1(1). pp. 24-35. https://doi.org/10.1016/j.jik.2016.02.001

CHEUNG, M. Y. - LUO, C. - SIA, C. L. - CHEN, H. (2009): Credibility of electronic word-of-mouth: Informational and normative determinants of on-line consumer recommendations. International Journal of Electronic Commerce. 13(4). pp. 9-38. https://doi.org/10.2753/JEC1086-4415130402

DEMIRAY, M. - BURNAZ, S. (2019): Exploring the impact of brand community identification on Facebook: Firm-directed and self-directed drivers. Journal of Business Research. 96. pp. 115-124. https://doi.org/10.1016/j.jbusres.2018.11.016

DIJKMANS, C. - KERKHOF, P. - BEUKEBOOM, C. J. (2015): A stage to engage: Social media use and corporate reputation. Tourism Management. 47. 
pp. 58-67.

https://doi.org/10.1016/j.tourman.2014.09.005

ECCLES, R. G. - NEWQUIST, S. C. - SCHATZ, R. (2007): Reputation and its risks. Harvard Business Review. 85(2). p. 104-14.

FOURNIER, S. - AVERY, J. (2011): The uninvited brand. Business Horizons. 54(3). pp. 193-207. https://doi.org/10.1016/j.bushor.2011.01.001

GAMBOA, A. M. - GONÇALVES, H. M. (2014): Customer loyalty through social networks: Lessons from Zara on Facebook. Business Horizons. 57(6). pp. 709-717. https://doi.org/10.1016/j.bushor.2014.07.003

JONES, B. - TEMPERLEY, J. - LIMA, A. (2009): Corporate reputation in the era of Web 2.0: the case of Primark. Journal of Marketing Management. 25(9-10). pp. 927-939.

https://doi.org/10.1362/026725709X479309

KOZINETS, R. V. (2015): Netnography: Redefined (2nd ed). Sage.

KÖKÉNY, L. - KENESEI, Z. - NESZVEDA, G. (2021): Impact of COVID-19 on different business models of European airlines. Current Issues in Tourism. Ahead of print. https://doi.org/10.1080/13683500.2021.1960284

KRIPPENDORFF, K. (2004): Content analysis. An introduction to its methodology. Thousand Oaks, CA: Sage.

LANCELOT-MILTGEN, C. - MIMOUNI CHAABANE, A. - PEZ-PÉRARD, V. (2019): The Dark Side of Customer Relationship Management Practices in the Data Age: Managing Resistance and Perceived Intrusion for Responsible Practices. In: N'Goala, G. - Pez-Pérard, V. - Prim-Allaz, I. (eds): Augmented Customer Strategy: CRM in the Digital Age. London: ISTE. pp. 219-239. https://doi.org/10.1002/9781119618324.ch13

LIAO, J. - HUANG, M. - XIAO, B. (2017): Promoting continual member participation in firm-hosted online brand communities: An organizational socialization approach. Journal of Business Research. 71. pp. 92-101.

https://doi.org/10.1016/j.jbusres.2016.10.013

MÁLOVICS É. - PRÓNAY SZ. - VAJDA B. (2015) $\mathrm{Az}$ „Erasmus-nemzedék” útra kel - Y generációs egyetemisták külföldi utazási motivációinak és szokásainak feltárása. Marketing $\mathcal{E}$ Menedzsment. 49(1). pp. 43-57.

MARKOS-KUJBUS É. - GERENCSÉR O. (2016): A negatív e-wom elsöprő ereje. JEL-KÉP. 4. pp. 17-32. https://doi.org/10.20520/JEL-KEP.2016.4.17

MARKOS-KUJBUS É. (2016): Az on-line szájreklám (electronic Word-Of-Mouth) jellemzői a marketingkommunikáció szempontjából. Vezetéstudomány. 47(6). pp. 52-63.

https://doi.org/10.14267/VEZTUD.2016.06.05
McALEXANDER, J. H. - SCHOUTEN, J. W. KOENIG, H. F. (2002): Building brand community. Journal of Marketing. 66(1). pp. 38-54. https://doi.org/10.1509/jmkg.66.1.38.18451

MUNIZ, A. M. - O'GUINN, T. (2001): Brand Community. Journal of Consumer Research. 27(4). pp. 412-432. https://doi.org/10.1086/319618

OMARLI, S. - CLARO D. - GYULAVÁRI T. (2018): Repülőjegyek dinamikus árazásának hatása a fogyasztók által észlelt méltányosságra. Turizmus Bulletin. 18(4). pp. 23-29.

PISKORSKI, M. J. (2011): Social strategies that work. Harvard Business Review. 89(11). pp. 116-122.

PORTER, C. E. (2004): A typology of virtual communities: A multi-disciplinary foundation for future research. Journal of Computer-Mediated Communication. 10(1). JCMC1011. https://doi.org/10.1111/j.1083-6101.2004.tb00228.x

SHAMMA, H. M. (2012): Toward a comprehensive understanding of corporate reputation: Concept, measurement and implications. International Journal of Business and Management. 7(16). pp. 151-169.

https://doi.org/10.5539/ijbm.v7n16p151

SUN, S. - LAW, R. - LUK, C. (2020): Tourists' travel-related information search channels. International Journal of Hospitality $\mathcal{E}$ Tourism Administration. https://doi.org/10.1080/15256480.2020.1727809

SZUTORISZ G. - SZABÓ B. - POCSAROVSZKY K. (2008): E-business-modellek a magyarországi diszkont légitársaságok piacán. Vezetéstudomány. 39(12). pp. 51-59. https://doi.org/10.14267/VEZTUD.2008.12.05

TASENȚE, T. (2020): Facebook's role in online reputation management. Technium Social Sciences Journal. 6(1). pp. 62-68.

VERMEER, S. - REMMELSWAAL, P. - JACOBS, S. (2017): Heineken in the house: improving online media reputation through featuring a sponsored brand community. Communication Management Review. 2(1). pp. 76-103. https://doi.org/10.22522/cmr20170117

ZHU, D. H. - CHANG, Y. P. - LUO, J. J. (2016): Understanding the influence of $\mathrm{C} 2 \mathrm{C}$ communication on purchase decision in online communities from a perspective of information adoption model. Telematics and Informatics. 33(1). pp. 8-16. https://doi.org/10.1016/j.tele.2015.06.001

\section{Internetes források}

BAIRD, C. H. - PARASNIS, G. (2011). From social media to Social CRM. IBM Institute for Business Value. URL: https://www.ibm.com/downloads/ cas/LD1VERKP, Letöltve: 2021. április 9. 